\title{
PEMBERDAYAAN EKONOMI DI PESANTREN BERBASIS SYARIAH
}

\author{
Moh. Toriquddin \\ Pasca Sarjana Institut Agama Islam Negeri Sunan Ampel Surabaya \\ Email:toriquddin@Yahoo.com
}

\begin{abstract}
Abstrak
Pesantren in Indonesia plays significant role in realizing the freedom of Indonesia and developin Islam. Nevertheless, its character is still ethico religious with the orientation of students' personality dimension building from religious supervision (diniyyah tahzibiyyah) and spiritual and mental supervision (Khalqiyyah). During its development, Pesantren is demanded to strengthen spiritual values internalization ('ubudiyyah). It is also a demand for its students to enrich responsibility values, rationality and problem solving skill. It is also a undeniable demand for pesantren to contribute the recent situation including its challenge. Otherwise, it does not merely focus on education to create scholars but also to crate skillful people that can contribute to the surrounding. This paper will discuss another side of Pesantren's role in this contemporary era.

Sejak zaman pra kemerdekaan hingga kini, pesantren di Indonesia memerankan peranan yang signifikan baik dalam langkah mewujudkan kemerdekaan maupun perkembangan agama Islam. Namun misi pesantren selama ini lebih bercorak ethico religious dengan orientasi pembentukan dimensi kepribadian anak didik baik dari segi pembinaan agama (diniyyah tahzibiyyah) dan pembinaan jasad, akal dan jiwa (Khalqiyyah). Pada perkembangannya, pesantren selain dituntut untuk memperkuat penanaman nilainilai spiritual ('ubudiyyah) kepada para santri, juga dituntut untuk memperkaya penanaman aspek tanggung jawab, rasionalitas dan pemecahan masalah. Pesantren di era modern dituntut untuk bisa menjawab tantangan zaman dan tidak hanya berkutat pada dunia pendidikan dalam arti hanya mencetak ilmuwan tetapi juga mencetak tenaga-tenaga terampil dan juga memberi manfaat pada lingkungan sekitar. Tulisan ini akan mendskusikan sisi lain dari peran pesantren pada era kontemporer ini.
\end{abstract}

Kata Kunci: Pesantren, Pemberdayaan, Ekonomi

Sejak masa penjajahan Belanda, pesantren memainkan peranan yang terbatas. Pesantren hanya mengkaji ilmuilmu keislaman klasik dengan nuansa kesederhanaan, bahkan sering diidentikkan dengan 'pedesaan'. Kehadiran pesantren di Indonesia tidak dapat dipungkiri lagi perannya. Di masa penjajahan, pesantren juga terlibat langsung dalam melawan penjajah. ${ }^{1}$ Peran pesantren sejak dulu

1 Mujamil Qamar, Pesantren dari Transformasi memang tidak pernah lepas dengan peran edukatif yang murni mengajarkan ilmu-ilmu keislaman. Pesantren dengan label pendidikan agama yang diemban, diharapkan akan berkontribusi penting dalam pembenahan 'kemiskinan spiritual' masyarakat. Kurikulum pesantren menawarkan kajian yang sangat penting yang tidak hanya terbatas pada bagaimana mem-

Metodologi Menuju Demokratisasi Institusi (Jakarta:: Erlangga, 2007), bu 23ith 
bangun relasi dengan Tuhan, namun juga relasi dengan sesama manusia maupun lingkungan. Penyajian pelajaran dibangun berdasarkan pada kekhasan budaya Indonesia yang sangat kental dengan nuansa kekeluargaan. Tipe penyajian pelajarannya sangat sederhana. Para santri menimba ilmu dengan cara bandongan atau wetonan dan sorogan. ${ }^{2}$

Pondok pesantren umumnya dikenal sebagai perguruan swasta yang berkemampuan tinggi dalam berswakarsa dan berswakarya dalam menyelenggarakan pendidikan. Misi mulia yang diembanya selama ini lebih bercorak ethico religious dengan orientasi pembentukan dimensi kepribadian anak didik baik dari segi pembinaan agama (diniyyah tahzibiyyah) dan pembinaan jasad, akal dan jiwa (Khalqiyyah). ${ }^{3}$ Di era modern Pesantren selain dituntut untuk memperkuat penanaman nilai-nilai spiritual ('ubudiyyah) kepada para santri, juga dituntut untuk memperkaya penanaman aspek tanggung jawab, rasionalitas dan pemecahan masalah. Tanggung jawab (responsibility) pada konteks ini diartikan sebagai sikap konsisten dan disiplin melaksanakan apa yang benar (doing what right). Rasionalitas artinya menggunakan akal sehat atau berorientasi pada pertanyaan mengapa. Sementara itu, pemecahan masalah adalah mengamalkan apa yang kita ketahui dan kuasai ke dalam tindakan (putting what you know and what you can do into action). ${ }^{4}$

Pesantren merupakan salah satu model dari pendidikan berbasis masyarakat. Kebanyakan pesantren berdiri atas inisiatif masyarakat muslim yang tujuan utamanya adalah untuk mendidik generasi muda agar memahamidan mengamalkan ajaran-ajaran

2 Ismail SM, Dinamika Pesantren dan Madrasah (Yogyakarta: Pustaka Pelajar, 2002), h. 53.

3 Muslih Usa dan Aden Wijdan, Pendidikan Islam Dalam Peradaban Industrial (Yogyakarta: Aditya Media, 1997), h. 12.

4 Abdurrahman Mas'ud, Reformasi Pendidikan Agama Menuju Masyarakat Madani, dalam Ismail SM dan Abdul Mukti (ed), Pendidikan Islam, Demokratisasi dan Masyarakat Madani (Cet I; Yogyakarta:: Pustaka Pelajar, 2000), h. 141.
Islam dengan baik. Pesantren dengan cara hidupnya yang bersifat kolektif barangkali merupakan perwajahan atau cerminan dari semangat dan tradisi dan lembaga gotong royong yang umum terdapat di pedesaan. ${ }^{5}$

Seiring dengan perjalanan bangsa kita, ketika lembaga-lembaga sosial yang lain belum berjalan secara fungsional maka pesantren telah menjadi pusat kegiatan masyarakat dalam belajar agama, bela diri, mengobati orang sakit, konsultasi pertanian, mencari jodoh, sampai pada menyusun perlawanan terhadap kaum penjajah. Tegasnya pesantren menjadi lembaga pendidik yang unik, tidak saja karena keberadaannya yang sudah sangat lama, tetapi juga karena kultur, metode dan jaringan yang diterapkan oleh lembaga pendidikan agama ini yang khas. Pesantren ini juga memiliki jaringan sosial yang kuat dengan masyarakat dan dengan sesama pesantren, karena sebagian besar pengasuh pesantren tidak saja terikat pada kesamaan pola pikir, paham keagamaan, namun juga memiliki hubungan kekerabatan yang cukup erat. ${ }^{6}$

Sejalan dengan derasnya arus perubahan sosial akibat modernisasi-industrialisasi mau tidak mau menuntut pesantren untuk memberikan reaksi atau respons secara memadai. Reaksi pesantren menghadapi perubahan yang berjalan selama ini ada yang lunak dan ada yang keras. Ada yang membuka dan ada yang menutup diri. Namun meski ada yang mendefinisikan zaman sekarang sebagai zaman edan atau jahiliyah modern, ternyata tidak sedikit yang mencoba melakukan transformasi dengan melakukan mobilitas budaya yang menyebabkan doktrin, lembaga dan pranata sosial menjadi tetap relevan. Selain itu, pesantren juga selalu dituntut untuk melakukan adjustment and readjustment ${ }^{7}$ mulai dari melakukan diversifikasi program de-

5 M. Dawam Raharjo, Pesantren dan Pembaharuan (Cet IV; Jakarta: LP3ES, 1988), h. 9.

6 Zamakhsyari Dhofier, Tradisi Pesantren: Studi tentang Pandangan Hidup Kiai (Jakarta: LP3ES, 1982), h. 60.

7 Azyumardi Azra, Pendidikan Islam, Tradisi dan Modernisasi Menuju Millenium Baru (Jakarta: Logos Wacana민. Ilmu, 1999), h. 108. 
ngan membuat yayasan, memasukkan sistem sekolah, kontekstualisasi kitab kuning, memodernisasi manajemen pengelolaan, reorientasi fungsi dengan memasukkan fungsi sosial ekonomi ke dalam program pesantren dan lain-lain.

Bersamaan dengan kemajuan ilmu pengetahuan dan teknologi, timbul beberapa kecenderungan masyarakat dalam melihat posisi, fungsi, dan peran pesantren. Disatu sisi, ada yang menilai pesantren merupakan lembaga pendidikan yang hanya mampu mencetak alumni yang memiliki kemampuan agama tanpa kemampuan yang dibutuhkan pasar, khususnya tenaga kerja. Pandangan seperti ini, menjadikan pesantren sebagai lembaga pendidikan 'pelarian'. Dalam menyikapi pandangan seperti ini, telah banyak pesantren yang memberikan bekal ketrampilan terhadap para santrinya. Pesantren tidak hanya membekali para santri dengan ilmu-ilmu keislaman tetapi telah memberikan ketrampilan yang bersifat aplikatif dan siap kerja. ${ }^{8}$

Tuntutan dan kebutuhan masyarakat juga berdampak terhadap eksistensi pesantren saat ini. Persepsi masyarakat yang masih kuat di seputar 'dunia kerja' menjadikan keberadaan suatu pesantren terancam.Kurangnyacivileffectyangdimiliki pesantren merupakan persoalan tersendiri. Kebanyakan orang tua menginginkan anakanaknya kelak setelah menyelesaikan studi akan mendapatkan pekerjaan dan bisa melanjutkan studi. Persoalan seperti ini masih membayangi pesantren, khususnya yang masih mempertahankan ciri khas 'kesalafiyahan'nya dengan sajian pelajaran agama yang lebih dominan karena pesantren merupakan cerminan dari dunia tradisional Islam. ${ }^{9}$

Tantangan yang dihadapi pesantren saat ini lebih kepada bagaimana kemampuannya menjawab tantangan global termasuk kemampuan pesantren melahirkan

8 Mujamil Qamar, Pesantren: Dari Transformasi Metodologi Menuju Demokratisasi Institusi (Jakarta:: Airlangga, 2007), h.79.

9 M. Dawam Raharjo, Pesantren dan Pembaharuan (Cet. IV; Jakarta: LP3ES, 1988), h. 42. intelektual-intelektual Islam yang memiliki kualitas daya saing yang tinggi. Di samping itu tuntutan dunia kerja akan memberikan beban bagi pesantren dalam menjawab persoalan ini. Dengan bekal pemahaman ilmuilmu keislaman yang baik, apakah akan membantu alumni mencari kerja? Apakah dengan kemampuan pengetahuan agama yang dimiliki, alumni dapat menjawab tantangan global?

Dari uraian dan pertanyaan-pertanyaan di atas dapat ditarik kesimpulan bahwa tugas pesantren di era sekarang sangatlah berat. Pesantren tidak hanya sekedar mengemban fungsi sebagai pencetak intelektual Islam yang handal di bidang ilmu keagamaan tetapi juga dituntut untuk bisa memberikan kontribusi secara riil, baik terhadap warga pesantren secara khusus maupun masyarakat luas secara umum. Kedua persoalan pokok tersebut, akan menjadi topik bahasan pada makalah ini.

\section{Pesantren Sebagai Pencetak Intelektual Muslim}

Pesantren sebagai lembaga pendidikan keagamaan merupakan realitas yang tidak dapatdipungkiri.Sepanjang sejarah yang dilaluinya, pesantren terus menekuni bidang pendidikan dan menjadikannya sebagai fokus kegiatan. Dalam mengembangkan pendidikan, pesantren telah menunjukkan daya tahan yang cukup kokoh sehingga mampu melewati berbagai zaman dengan beragam masalah yang dihadapinya. Dalam sejarahnya itu pula, pesantren telah menyumbangkan sesuatu yang tidak kecil bagi Islam di Negeri ini.

Sungguhpun demikian pesantren tak dapat berbangga hati dan puas dengan sekadar mampu bertahan atau terhadap sumbangan yang diberikan di masa lalu. Signifikansi pesantren bukan hanya terletak pada dua hal tersebut, tetapi pada kontribusinya yang nyata bagi umat Islam, secara khusus, dan masyarakat secara luas, di masa kini dan mendatang.

Hampir dapat disepakati, pesantren meCreated with

(n) nitro $^{\text {PDF }^{\prime} \text { professional }}$ 
rupakan lembaga pendidikan Islam tertua di Jawa. Munculnya pesantren di Jawa bersamaan dengan kedatangan para Wali Sanga yang menyebarkan Islam di daerah tersebut. Menurut catatan sejarah tokoh yang pertama kali mendirikan pesantren adalah Syaikh Maulana Malik Ibrahim. Pola tersebut kemudian dikembangkan dan dilanjutkan oleh para Wali yang lain.

Salah satu kelebihan dari model pendidikan yang dikembangkan para Wali Sanga itu (dan kemudian menjadi ciri khas pendidikan pesantren) terletak pada pola pendekatannya yang didasarkan pada segala sesuatu yang sudah akrab dengan masyarakat dan perpaduan antara aspek teoritis dan praktis. Misalnya, Sunan Giri menggunakan pendekatan permainan untuk mengajarkan Islam kepada anak-anak, Sunan Kudus menggunakan dongeng, Sunan Kalijaga mengajarkan Islam melalui wayang kulit, dan Sunan Drajat mengenalkan Islam melalui keterlibatan langsung dalam rangka menangani kesengsaraan yang dialami masyarakat. ${ }^{10}$

Pola itu telah mengantarkan pesantren pada system pendidikan yang penuh kelenturan dan memiliki spektrum luas, melampaui batas-batas pesantren itu sendiri. Tidak berlebihan jika dikatakan, pesantren merupakan deschooling society dengan menjadikan masyarakat, sebagai masyarakat pembelajar dan menjadikan belajar sebagai proses berjalan terus-menerus. Masyarakat menjadi bebas dari sekolah sebagai institusi dengan aturan-aturannya, system evaluasinya, janji-janji pekerjaan yang diberikannya, serta sertifikat yang dikeluarkannya. ${ }^{11}$ Pola ini pada gilirannya, menjadikan pendidikan pesantren tidak membuat batas secara tegas antara santri itu sendiri dan masyarakat yang ada di sekitarnya. Demikian pula, pesantren tidak membatasi waktu belajar dalam sekat-sekat

10 Marwan Sarijo, Sejarah Pondok Pesantren di Indonesia (Jakarta: Dharma Bhakti, 1982), h. 22-24.

11 Habib Chirzin, "Teguh pada Nilai Salaf dan Ahlussunnah wal Jama'ah" Rubrik Wawasan dalam Jurnal Pesantren (No I, Oktober-Desember, 1984), h. 39. waktu yang kaku sehingga proses pembelajaran dan pendidikan selama dua puluh empat jam hadir penuh dalam bentuk yang nyata tanpa harus "memberatkan" siapa pun yang terlibat di dalamnya.

Keberadaan pesantren diperkuat dengan tradisi keilmuan yang integral. Pada masanya integralitas itu dapat dilacak pada pengembangan figh dan alat-alat bantunya yang disatukan dengan figh sufistik. Dengan kata lain, yang diutamakan di dunia pesantren bukan hanya aspek pengamalan hukum atau aspek akhlak semata, melainkan juga pemekaran pengertian tentang kehidupan dan hakikat manusia serta kehidupan bermasyarakat. ${ }^{12}$ Dengan demikian antara proses pembelajaran dan pendidikan serta intelektualisme dan spiritualitas menyatu dalam satu kerangka nilai-nilai yang diyakini pesantren.

Hal lain yang hingga kini masih dimiliki pesantren adalah penekanannya pada nilainilai yang dianutnya, seperti kemandirian, kesederhanaan, dan keikhlasan. Nilai-nilai dasar ini dibingkai dengan paradigma yang sangat menekankan kepada apresiasi terhadap segala tradisi yang baik sekaligus akomodatif terhadap bentuk-bentuk reformasi yang dapat dipertanggung jawabkan. Nilai-nilai yang cukup kental di dunia pesantren ini pada prinsipnya merupakan nilainilai keagamaan yang otentik yang memiliki benang merah kuat dengan kesejarahan umat dan normativitas Islam hakiki.

Hasil dari semua itu adalah kehadiran pesantren sebagai institusi yang mampu memberikan sumbangan penting dan krusial dalam proses transmisi ilmu-ilmu Islam, reproduksi ulama, pemeliharaan ilmu dan tradisi Islam, bahkan pembentukan dan ekspansi masyarakat Muslim Santri. ${ }^{13} \mathrm{Ke}-$ nyataan itu telahmembuat lembaga tersebut memiliki keunggulan yang cukup signifikan. Pesantren memilki pengaruh cukup

12 Abdurrahman Wahid, "Asal-Usul Tradisi Keilmuan Pesantren" Jurnal Pesantren (No I, OktoberDesember, 1984), h. 8-10.

13 Azyumardi Azra, Konteks Berteologi di Indonesia: Pengalaman Islam (Cetakan I; Jakarta:: Paramadinate 999 h h h. 184-185. 
besar di kalangan masyarakat, khususnya di pedesaan. Di samping itu, di kalangan para santri berkembang solidaritas cukup tinggi, toleransi dalam menjalankan tugas, dan rasa pengorbanan cukup besar bagi kepentingan umum. Kelebihan tersebut menjadikan pesantren memiliki potensi atau peluang cukup besar sebagai agen pembangunan ${ }^{14}$ tanpa harus tergantung kepada teori developmentalisme yang kapitalistik. Hal ini menjadikan keberadaan pesantren sebagai lembaga dan system pendidikan alternatif, jika dirumuskan secara arif, akan berlabuh nyata di bumi Indonesia.

Kontekstualisasi nilai-nilai tradisi menjadi keniscayaan untuk dibumikan dalam realitas pendidikan pesantren. Kesederhanaan, kemandirian, dan keikhlasan perlu dijadikan ruh pendidikan dalam suatu rumusan kontekstual yang sesuai perkembangan dan perubahan kehidupan yang terus berjalan. Dengan demikian, kesederhanaan akan menemukan titik labuhnya pada pengembangan efisiensi dan evektivitas lembaga, dan kemandirian akan diarahkan kepada pembentukan civil society, serta keikhlasan akan dikonkretkan ke dalam bentuk pengembangan prestasi.

Pendidikan (pengajaran inklusif) berbagai disiplin ilmu dan pengembangan metodologi yang lebih manusiawi dan religius akan menjadi kemestian yang tidak dapat diingkari untuk ditumbuh kembangkan. Semua itu dijalankan bukan karena sekedar latah yang bersifat formalistik, tetapi benarbenar berangkat dari tradisi pesantren yang pada prinsipnya, merupakan ajaran dan nilai Islam otentik. Oleh karena itu pengembangan ilmu-ilmu yang bersifat umum tidak diletakkan sekadar sebagai pelengkap tanpa makna terhadap ilmu-ilmu syariah, atau akan menjadi sesuatu yang asing yang harus ditolak. Justru hal itu akan diintegrasikan secara penuh dengan ilmu syariah sehingga kian mengokohkan keyakinan manusia tentang realitas Tuhan sebagai sumber dan Pencipta segala sesuatu.

14 Abdurrahman Wahid, Pergulatan Negara, Agama, dan Kebudayaan (Jakarta: Desantara, 2001), h. 133.
Aspek penumbuhan keyakinan tersebut di atas merupakan the ultimate goal yang perlu dicapai oleh pesantren. Sebab penilaian tentang keberhasilan pesantren sebagai pendidikan alternatif terletak, salah satunya, pada kemampuannya menyumbangkan pembangunan (mental) spiritual melalui pemberian ruang yang cukup untuk emotionalization of religious feeling yang diekspresikan secara intelektual..$^{15}$ Selain itu, juga berpijak pada ketulusan pesantren untuk tetap menyatu dengan masyarakat sekaligus sebagai agen transformasi yang dapat mencerahkan mereka.

Sekalipun sampai saat ini tujuan pendidikan di pesantren belum dirumuskan secara rinci dan dijabarkan dalam suatu system pendidikan yang lengkap dan konsisten, tetapi secara umum tujuan itu tertuang dalam kitab Talimul Mutata'alim, di mana tujuan seseorang menuntut ilmu dan mengembangkan ilmu adalah semata-mata karena kewajiban Islam yang harus dilakukan secara ikhlas. ${ }^{16}$

Tujuan ini pada gilirannya akan menjadi faktor motivasi bagi para santri untuk belajar melatih diri menjadi seorang yang ikhlas di dalam segala amal perbuatannya. Karena seseorang yang belajar di pesantren berdasar azaz keikhlasan, maka apabila ia telah lulus dari pesantren tidak boleh memiliki pamrih apapun.

Sehingga terdapat pernyataan dari kalangan pesantren bahwa tujuan pendidikan di pesantren adalah membentukmanusia yang bertaqwa, mampu hidup dengan kekuatan sendiri, tidak merupakan keharusan untuk menjadi pegawai negeri. ${ }^{17}$ Dengan demikian dapat disimpulkan bahwa secara umum tujuan pendidikan di pesantren adalah mendidik manusia yang mandiri.

Sekalipuntujuanpendidikandipesantren belum secara rinci dan dijabarkan dalam

15 Zamakhsyari Dhafir, Tradition and Change in Indonesian Islamic Education (Jakarta: Office of Religious Research, 1995), h. 86.

16 A. Zarnudji, Kitab Ta'limul Muta'alim (Kudus: Menara Kudus, 1963), h. 1.

17 Dawam Raharjo, Pesantren dan Pembaharuan (Jakarta: LP3S 1974) it the 58. 
suatu system pendidikan yang lengkap dan konsisten, tetapi secara sistematis tujuan pendidikan di pesantren jelas menghendaki produk lulusan yang mandiri dan berakhlak baik serta bertaqwa, dengan memilahkan secara tegas antara aspek pendidikan dan pengajaran yang keduanya saling mengisi satu dengan yang lain. Singkatnya, dimensi pendidikan dalam arti membina budi pekerti anak didik memperoleh porsi yang seimbang di samping dimensi pengajaran yang membina dan mengembangkan intelektual anak didik.

Dengan adanya harmonisasi antara dimensi pendidikan dan dimensi pengajaran, makatujuan pengajarandipesantrenmenjadi jelas. Tujuan pendidikan di pesantren tidak semata-mata untuk memperkaya pikiran murid dengan penjelasan-penjelasan, tetapi untuk meninggikan moral, melatih dan mempertinggi semangat, menghargai nilai-nilai spiritual dan kemanusiaan, membentuk sikap dan tingkah laku yang jujur dan bermoral, dan menyiapkan para murid untuk hidup sederhana dan bersih hati. ${ }^{18}$

Salah satu tujuan pendidikan pesantren adalah latihan untuk dapat berdiri sendiri dan membina diri agar tidak menggantungkan sesuatu kepada orang lain kecuali kepada Tuhan. Karena itu dalam banyak hal yang paling ditekankan kepada muridmurid adalah pentingnya keikhlasan di atas segalanya.

Karena tujuan pendidikan pesantren seperti itu, maka yang paling ditekankan adalah pengembangan watak pendidikan individual yang berorientasi pada selfemployment dan sosial employment. ${ }^{19}$ Muridmurid dididik sesuai dengan kemampuan dan keterbatasan dirinya, sehingga di pesantren dikenal prinsip-prinsip dasar belajar tuntas dan maju berkelanjutan. Anakanak yang cerdas dan memiliki kelebihan

18 Zamakhsyari Dhofier, Tradisi Pesantren, Studi Tentang Pandangan Hidup Kiai (Jakarta: LP3ES, 1984), h.21.

19 A. Sunyoto, Ajaran Tasawuf dan Pembinaan Sikap Hidup Santri Pesantren Nurul Haq Surabaya: Studi Kasus "Tesis tidak dipublikasikan" (Malang: FPS IKIP, 1989), h. 5. kemampuan dari pada yang lain akan diberi perhatian istimewa dan selalu didorong untuk terus mengembangkan diri dan menerima kuliah pribadi secukupnya. Murid-murid diperlakukan sebagai makhluk yang terhormat sebagai titipan Tuhan yang harus disanjung. ${ }^{20}$

\section{Pesantren dan Pemberdayaan Masyarakat}

Pendayagunaan zakat untuk pemecahan problem kemiskinan

Menurut Kiai Sahal, zakat kurang sesuai jika semata-mata dipahami secara legal formal seperti diatur dalam buku-buku fiqh namun harus dipahami secara lebih luas. Zakat, bagi kiai Sahal, di samping berfungsi sebagai sarana untuk beribadah dan mendekatkan diri kepada Allah (li al-taqarrub), juga memiliki fungsi sosial yang amat besar yaitu sebagai sarana mempersempit jurang perbedaan pendapatan dalam masayarakat sehingga bisa menghapus kesenjangan antara golongan miskin dan kaya. ${ }^{21}$ Jadi, zakat membawa dua misi sekaligus yaitu misi ubudiyyah yang wajib dipenuhi umat Islam juga membawa misi sosial untuk memberdayakan ekonomi umat Islam.

Untuk merealisasikan misi tersebut, kewajiban zakat hanya dibebankan kepada orang-orang kaya dan diberikan kepada orang-orang yang membutuhkan. Dengan demikian zakat menjadi mekanisme institusional untuk mewujudkan keadilan sosial. Hal ini dimungkinkan karena zakat bisa menekan akumulasi modal pada sekelompok kecil masyarakat serta menghilangkan potensi disparitas sosial antara kelompok kaya dan miskin.22 Pada gilirannya, zakat secara mandiri diharapkan mampu menjadi wahana rehabilitatif terhadap kerawanan ekonomi serta

\footnotetext{
20 Zamakhsyari Dhofier, Tradisi Pesantren., h. 22.

21 Sasongko Tedjo (ed.), Dialog Dengan KH MA Sahal Mahfudh (Semarang: Yayasan Karyawan Suara Merdeka, 1997), h. 39.

22 MA.Sahal Mahfudh, "Fungsi Zakat dan Pengelolaannya", dalam Kumpulan Makalah KH. MA Sahal Mahfudh (Pati: Pesantren Maslakul Huda, 30 Maret 1989),, th with
} 
berangsur-angsur mengurangi kemiskinan.

Namun cara pembagian zakat yang dipelihara kebanyakan masih berpola tradisional dan bersifat konsumtif. Akibatnya, begitu jatah zakat diperoleh akan langsung habis dimakan. Dengan demikian, bukan mustahil jika pengelolaan zakat secara tradisional ini dipertahankan akan menyebabkan munculnya efek sampingan. Zakat justru akan menimbulkan sikap fatalistic di kalangan dhu'afa' karena rasa tamaknya yang besar atas pembagian zakat yang secara rutin diterima. ${ }^{23}$ Zakat lalu akan menimbulkan kerawanan mental tersendiri yang dapat berakibat mematikan kreativitas dan etos kerja para penerimanya dan menstrukturkan kemalasan yang berarti mengabadikan kemiskinan.

Menyadari akan kelemahan dalam mekanisme pengelolaan zakat ini maka Kiai Sahal menyerukan perlunya profesionalisme pengelolaan zakat. Pengelolaan zakat secara professional memerlukan tenaga-tenaga terampil yang menguasai masalah-masalah yang berhubungan dengan zakat seperti muzakki, nisab, haul dan mustahiq zakat. Selain itu pengelola zakat harus terdiri dari orang-orang penuh dedikasi, bekerja lillahi ta'ala, jujur dan amanah. ${ }^{24}$

Selanjutnya menurut Kiai Sahal, zakat yang dikelola pemerintah sebaiknya dibayarkan bukan dalam bentuk uang. Sehingga jika si mustahiq punya keterampilan menjahit, maka berilah mesin jahit. Jika keterampilannya hanya mampu mengemudikan becak, berilah becak..$^{25}$

Kiai Sahal telah mencoba memotivasi warga di tiga desa. Zakat yang terkumpul dilembagakan. Salah satu di antaranya dilembagakan dalam bentuk koperasi. Panitia (bukan amil) bertugas hanya sekadar mengumpulkan zakat dan mengatur pembagiannya. Hasilnya tidak langsung dibagikan dalam bentuk uang, tetapi diatur sedemikian rupa supaya tidak bertentangan

23 MA. Sahal Mahfudh, Nuansa Fiqh Sosial (cet II; Yogyakarta: LKiS, 2003), h. 120.

24 MA. Sahal Mahfudh, Nuansa., h. 147.

25 MA. Sahal Mahfudh,"Dakwah Untuk Kaum Dhua'afa'" dalam Figh Sosial (Yogyakarta: LKiS, 1994), h. 121 . dengan agama. Mustahiq diserahi zakat berupa uang, tetapi kemudian ditarik kembali sebagai tabungannya untuk keperluan pengumpulan modal.

Dengan cara ini mereka menciptakan pekerjaan dengan modal yang dikumpulkan dari harta zakat. Ternyata berhasil. Meskipun kita tidak bisa melenyapkan atau mengahapuskan kemiskinan sama sekali, paling tidak kita telah berhasil menguranginya. ${ }^{26}$

\section{Pelestarian lingkungan hidup}

Kiai Sahal memandang, penggunaan sumber daya alam harus didasarkan pada aspek manfaat dan maslahat. ${ }^{27}$ Ajaran Islam jelas-jelas mengingatkan pada manusia untuk menggunakan dan memanfaatkan sumber daya yang disediakan di alam disertai upaya melestarikan lingkungan hidup. Sebaliknya merupakan tindakan mubadzir dan mencelakakan jika manusia tidak memanfaatkan sumber daya alam. Namun diingatkan Kiai Sahal, penggunaan sumber daya alam harus memenuhi ukuran-ukuran kemanfaatan dan kemaslahatan. Pemanfaatan sumber daya alam harus diorientasikan untuk memenuhi kebutuhan hidup manusia, diarahkan kepada kepentingan hidup, kepentingan bersama, kepentingan agama dan lain-lain.

Menurut Kiai Sahal, pembangunan harus memperhatikan aspek keseimbangan dan kelestarian lingkungan hidup. Hal ini mengingat upaya pelestarian lingkungan menjadi kunci bagi penciptaan kesejahteraan di dunia dan akhirat. Upaya pelestarian lingkungan diakui Kiai Sahal menyangkut upaya-upaya perlindungan terhadap berbagai kekayaan alam mulai dari tumbuh-tumbuhan, air, hewan dan unsur-unsur alam lainnya.

Upaya-upaya menjaga keselamatan lingkungan hendaknya menjadi kesadaran bersama. Semua elemen masyarakat harus bersinergis untuk merealisasikan gerakan ini. Di antara elemen sosial yang

26 MA. Sahal Mahfudh, Nuansa., h. 123.
27 MAA.Sahthliklahfudh, Nuansa., h. 29. 
bisa mengambil peranan penting dalam upaya pelestarian lingkungan adalah institusi pesantren. Pesantren diyakini Kiai Sahal bisa melaksanakan peran ini mengingat posisinya yang menyatu dengan masyarakat. Pesantren sebagai lembaga pendidikan keagamaan mempunyai fungsi ganda. ${ }^{28}$ Pertama, sebagai lembaga pendidikan yang mampu mengembangkan pengetahuan, penalaran, keterampilan, kepribadian kelompok muda dan merupakan sumber referensi tata nilai Islami bagi masyarakat sekitar. Ke$d u a$, sebagai lembaga sosial di pedesaan yang dapat menggerakkan swadaya dan swakarsa masyarakat khususnya dalam melakukan perbaikan lingkungan.

Upaya pembinaan lingkungan hidup, menurut Kiai Sahal dapat dilakukan dengan dua pendekatan. ${ }^{29}$ Pertama, pendekatan proyek. Kedua, pendekatan motivasi. Atau keduanya dilakukan secara sekaligus. Pendekatan motivasi ini bisa dilakukan melalui jalur pendidikan di pesantren. Pendekatan motivasi walaupun memerlukan waktu relatif lama, diyakini akan memberi dampak lebih positif, karena kelompok sasaran secara berangsur akan mau mengubah sikap dan perilakunya secara persuasive. Perilaku dan sikap acuh tak acuh mereka kepada masalah lingkungan hidup akan berubah menjadi sikap dinamis terhadap pembinaan lingkungan hidup.

Keterlibatan pesantren dalam memberikan pengertian mengenai dampak lingkungan hidup bagi kehidupan manusia merupakan salah satu bentuk kontribusi dari unsur-unsur di luar pemerintah dalam pembinaan lingkungan hidup. Bila upayaupaya pembinaan lingkungan hidup dilembagakan dalam wadah/organisasi, maka akan memberi pengaruh lebih luas dibandingkan jika dikelola tanpa lembaga.

Upaya-upaya penanaman kesadaran bersama untuk menjaga kelestarian lingkungan seperti dilakukan oleh Kiai Sahal pada saat sekarang ini kian menemukan

28 MA. Sahal Mahfudh, Nuansa., h. 370.

29 MA. Sahal Mahfudh, Nuansa., h. 372. momentumnya. Alasannya, pada saat ini dunia dihantui oleh krisis lingkungan hidup. Kualitas sumber daya alam yang tersedia di darat dan di laut sudah semakin merosot(degradasi). Menyadarihalitu, maka sekarang sedang marak disosialisasikan model pembangunan berkelanjutan (sustainable development) atau pembangunan berwawasan lingkungan. Suatu pembangunan dianggap berkelanjutan jika kegiatannya selain memenuhi persyaratan ekonomi juga memenuhi persyaratan sosial budaya. Oleh karena itu, pembangunan berkelanjutan senantiasa menghendaki peningkatan kualitas hidup manusia dan selalu berorientasi jangka panjang dengan prinsip-prinsip keberlanjutan hidup manusia sekarang dan akan datang. ${ }^{30}$

Secara umum ada lima prinsip utama dalam pembangunan berkelanjutan. Pertama, keadilan antar generasi (Intergenerational equity ). Prinsip ini berangkat dari suatu gagasan bahwa generasi sekarang menguasai sumber daya alam yang terdapat di muka bumi sebagai titipan untuk dipergunakan generasimendatang. Kedua, prinsipkeadilan dalam satu generasi(Intragenerationalequity) merupakan prinsip yang berbicara tentang keadilan di antara sesama satu generasi termasuk dalam memenuhi kebutuhan-kebutuhan atau tidak terdapat kesenjangan antara individu dan kelompok-kelompok dalam masyarakat. ${ }^{31}$ Ketiga, prinsip pencegahan dini (Precautionary principle). Prinsip ini mengandung pengertian; tidak ada alasan untuk menunda upaya-upaya untuk mencegah kerusakan lingkungan apabila terdapat ancaman kerusakan lingkungan yang tidak dapat dipulihkan. Keempat, prinsip perlindungan keaneka ragaman hayati (biodiversity conservation). Keaneka ragaman hayati perlu dilindungi karena memberikan dan menjadi sumber kesejahteraan bagi umat manusia. Kelima, perlunya internalisasi biaya lingkungan dan mekanisme insentif. Gagasan dari

30 Jonny Purba, Pengelolaan Lingkungan Sosial (Jakarta: Kantor Kementrian Lingkungan Hidup dan Yayasan Obor Indonesia, 2002), h. 13.

31 crlongy Purba, Pengelolaan., h. 18. 
prinsip ini adalah biaya lingkungan dan sosial harus diintegrasikan ke dalam proses pengambilan keputusan yang berkaitan dengan penggunaan sumber-sumber daya alam. Sedangkan mekanisme insentif berupa program peringkat kinerja yang dimaksudkan untuk mengubah perilaku dan nilai-nilai di masyarakat melalui publikasi kenerja industri secara periodik. ${ }^{32}$

Beberapa penyebab kerusakan hutan adalah maraknya praktik industri pertambangan yang kurang memperhatikan aspek keselamatan ekologis, eksploitasi kayu hutan dan kebakaran yang merusak areal hutan. Di lokasi-lokasi pertambangan terlihat jelas bagaimana wajah hutan Indonesia yang hancur karena penggalian, pembuangan limbah batuan dan limbah tailing (sisa-sisa pertambangan) serta aktifitas penunjang operasi tambang lainnya. Beberapa perusahaan yang akan menghentikan kegiatan tambangnya menyatakan tidak mampu menghutankan kembali bekas-bekas lubang tambang dan kolam limbah mereka. Lubang-lubang itu dibiarkan terus menganga dan menjadi danau asam beracun pasca penambangan. Begitu pula kolam limbah tailing akan jadi hamparan pasir yang mengandung logam berat dalam kurun waktu sangat panjang.

Komitmen Kiai Sahal terhadap pentingnya pelaksanaan program pembangunan yang berwawasan lingkungan sedikit banyak telah ikut mewarnai sejumlah keputusan yang dilahirkan NU. Salah satu produk pemikiran NU yang memberikan apresiasi terhadap upaya menjaga keselamatan lingkungan dapat disimak dalam Hasil Keputusan Mukatamar ke-30 pada tanggal14Nopember 1999 di Lirboyo Kediri. Sebagian isi hasil muktamar mengkritisi model pembangunan pemerintah yang selama ini dinilai telah mengabaikan faktor keseimbangan dan kelestarian alam. ${ }^{33}$

\section{Relokasi prostitusi}

32 Jonny Purba, Pengelolaan., h. 19.

33 LDNU, Masail Diniah Muktamar NU ke-30 di Lirboyo Kediri 24 Nopember 1999 (Jakarta: LDNU) http://ldnu.org/fatwa/arsip/000578.shtml.
Dalam situasi apapun, pelacuran selalu saja hadir, dari yang mengendap-endap hingga yang terang-terangan. Pelacuran telah beringsut dan menggurita menjadi industri seks yang tak pernah sepi dari hiruk pikuk konsumen sehingga keberadaanya menjelma bagai "benang ruwet" yang sulit dihindari. Sebab, pelacuran selalu saja berhimpitan dengan wilayah sosial, kekuasaan politik, dan ekonomi, bahkan lembaga keagamaan.

Ketika berhadapan dengan masalah prostitusi dan industri seks Kiai Sahal cenderung menjadikan kaidah idza ta'aradla mafsadatani ru'iya a'dzamuhuma dlararan bi al-irtikabi akhaffihima sebagai dasar dalam memberikan ketetapan hukum fikih. ${ }^{34} \mathrm{Me}-$ nurutnya, prosttitusi jelas merupakan sesuatu yang dilarang agama. Akan tetapi sebagai persoalan sosial yang sangat komplek, prostitusi bukanlah persoalan yang mudah untuk dihilangkan. Dalam kondisi semacam itu kita dihadapkan pada dua pilihan yang sama-sama mafsadat, yaitu membiarkan prostitusi tidak terkontrol di tengah masyarakat, atau melokalisir sehingga prostitusi bisa terkontrol. Pilihan terhadap kebijakan lokalisasi prostitusi merupakan pilihan yang didasarkan atas prinsip memilih perbuatan yang dampak buruknya lebih ringan. Dengan demikian, tinjauan fiqh sosial membenarkan tindakan lokalisasi terhadap para wanita pekerja seks komersial.

Menurut Kiai Sahal ada dua cara terbaik dalam menanggulangi prostitusi. Pertama, melalui sentralisasi lokasi pelacuran yakni melokalisasi pelacuran dari suatu tempat yang jauh dari kontak penduduk. Kedua, melalui pendekatan kausatif-sosiologis. Pendekatan pertama dimaksudkan sebagai "jalan tengah" dari dua arus pemikiran yakni kalangan yang tetap menginginkan prostitusi seperti apa adanya dan kalangan yang bersikeras menghapus pelacuran. Dalam pengamatan KiaiSahal, pola pikir kedua kelompok ini sama-sama menimbulkan madlarat. ${ }^{35}$

34 MA. Sahal Mahfudh, Nuansa., h. xiii.

35 Sumanto al-Qurtuby, "Proyek Membangun 
Pola pikir pertama yakni yang membiarkan pelacuran karena meskipun pemikiran ini mempunyai nilai positif, namun oleh Kiai Sahal tetap dinilai madlarat karena pola itu berarti merestui "lembaga kemaksiatan" dan promiskuitas. Cara berpikir demikian tentunya tidak sesuai dengan kaidah ushul fiqh yang menyatakan ar-ridla bi al-syai' ridlan bi ma yatawalladu minhu (rela terhadap sesuatu berarti rela terhadap sesuatu yang dilahirkannya). Dengan kata lain, berdiam diri dari pelacuran tanpa ada pencegahan berarti orang tersebut merelakan terhadap berbagai akses negative yang ditimbulkan dari pelacuran.

Demikian juga dengan pola pikir yang menghendaki penghapusan total terhadap pelacuran tentunya tidak dapat menyelesaikan masalah, justru sebaliknya menimbulkan permasalahan baru. Sebab dengan ditutupnya "saluran resmi seks" akan menimbulkan apa yang disebut "seks liar" yang justru dampak negatifnya lebih besar ketimbang yang pertama.

Solusi perlunya dilakukan sentralisasi lokasi pelacuran (tempat yang pernah diusulkan Kiai Sahal adalah Nusakambangan dan Karimunjawa) merupakan tawaran pemecahan dalam rangka meminimalisasi madlarat pelacuran secara proporsional. al ini bagaimanapun pelacuran sebagaimana berbagai bentuk kemaksiatan lain tidak dapat dihapuskan, namun yang bisa dilakukan adalah meminimalisasi. Pendapat Kiai Sahal itu didasarkan pada kaidah akhaf al-dlararain yaitu mengambil sikap yang resikonya paling kecil dari dua macam bahaya.

Cara kedua yang ditawarkan Kiai Sahal dalam menanggulangi prostitusi adalah dilakukan dengan pendekatan kausatifsosiologis (sad al-dzariah) yaitu dengan menelusuri latar belakang para pelaku dan usaha-usaha menjauhkan sebab-sebab yang mengakibatkan timbulnya perbuatan zina dan kebebasan seks. ${ }^{36}$ pendekatan ini

Jalan Tengah", dalam Tashwirul Afkar (Jakarta:: Lakpesdam NU, Edisi 9 Tahun 2000), h. 113.

36 MA Sahal Mahfudh, "Aids dan Prostitusi dari dilakukan mengingat sesungguhnya yang turut melestarikan pelacuran bukan semata kaum perempuan tetapi juga kaum lakilaki, masyarakat, penguasa, bahkan bisa jadi pemimpin agama sendiri.

\section{Kesimpulan}

Pesantren dari dulu hingga sekarang tidak dapat dipungkiri telah memberi andil yang signifikan dalam dunia pendidikan di Indonesia. Salah satu kelebihan dari model pendidikan pesantren terletak pada pola pendekatannya yang didasarkan pada segala sesuatu yang sudah akrab dengan masyarakat dan perpaduan antara aspek teoretis dan praktis.

Pesantren memiliki pengaruh cukup besar di kalangan masyarakat, khususnya di pedesaan. Di samping itu, di kalangan para santri berkembang solidaritas cukup tinggi, toleransi dalam menjalankan tugas, dan rasa pengorbanan cukup besar bagi kepentingan umum.

Tujuan pendidikan di pesantren adalah membentuk manusia yang bertaqwa, mampu hidup dengan kekuatan sendiri, tidak merupakan keharusan untuk menjadi pegawai negeri. Dengan demikian dapat disimpulkan bahwa secara umum tujuan pendidikan di pesantren adalah mendidik manusia yang mandiri.

Dalam masalah zakat, Kiai Sahal telah mencoba memotivasi warga di tiga desa. Zakat yang terkumpul dilembagakan. Salah satu di antaranya dilembagakan dalam bentuk koperasi. Panitia (bukan amil) bertugas hanya sekadar mengumpulkan zakat dan mengatur pembagiannya. Hasilnya tidak langsung dibagikan dalam bentuk uang, tetapi diatur sedemikian rupa supaya tidak bertentangan dengan agama.Mustahiq diserahi zakat berupa uang, tetapi kemudian ditarik kembali sebagai tabungannya untuk keperluan pengumpulan modal.

Selanjutnya Kiai Sahal memandang, penggunaan sumber daya alam harus didasarkan pada aspek manfaat dan masDimensi Islam", makalah disampaikan dalam Seminar Yaski (Yogyakarta:21 Juni 1987), h. 12. 
lahat. Upaya pembinaan lingkungan hidup, menurut Kiai Sahal dapat dilakukan dengan dua pendekatan. Pertama, pendekatan proyek. Kedua, pendekatan motivasi. Atau keduanya dilakukan secara sekaligus. Pendekatan motivasi ini bisa dilakukan melalui jalur pendidikan di pesantren. Pendekatan motivasi walaupun memerlukan waktu relative lama, diyakini akan memberi dampak lebih positif, karena kelompok sasaran secara berangsur akan mau mengubah sikap dan perilakunya secara persuasif.

Ketika berhadapan dengan masalah prostitusi dan industry seks Kiai Sahal cenderung menjadikan kaidah idza ta'aradla mafsadatani ru'iya a'dzamuhuma dlararan bi al-irtikabi akhaffihima sebagai dasar dalam memberikan ketetapan hukum fikih.

\section{DAFTAR PUSTAKA}

Al-Qurtuby,Sumanto. 2000. " Proyek Membangun Jalan Tengah", dalam Tashwirul Afkar. Jakarta: Lakpesdam.

Azra,Azyumardi. 1999. Konteks Berteologi di Indonesia: Pengalaman Islam. Cetakan I Jakarta: Paramadina.

--o-----o. 1999. Pendidikan Islam, Tradisi dan Modernisasi Menuju Millenium Baru. Jakarta: Logos Wacana Ilmu.

Chirzin,Habib. 1984. "Teguh pada Nilai Salaf dan Ahlussunnah wal Jama'ah" Rubrik Wawasn dalam Jurnal Pesantren. No. Perdana, Oktober-Desember.

Dhafir,Zamakhsyari. 1995. Tradition and Change in Indonesian Islamic Education. Jakarta: Office of Religious Research.

1984. Tradisi Pesantren, Studi Tentang Pandangan Hidup Kiai. Jakarta: LP3ES.

LDNU, Masail Diniah Muktamar NU ke-30 di Lirboyo Kediri 24 Nopember 1999, Jakarta: LDNU)http://ldnu.org/fatwa/ arsip/000578.shtml.

Mahfudh, MA. Sahal. 2003. Nuansa Figh Sosial. cet II. Yogyakarta: LkiS. 1989. "Fungsi Zakat
Menurut Kiai Sahal ada dua cara terbaik dalam menanggulangi prostitusi. Pertama, melalui sentralisasi lokasi pelacuran yakni melokalisasi pelacuran dari suatu tempat yang jauh dari kontak penduduk. Kedua, melalui pendekatan kausatif-sosiologis. Pendekatan pertama dimaksudkan sebagai "jalan tengah" dari dua arus pemikiran yakni kalangan yang tetap menginginkan prostitusi seperti apa adanya dan kalangan yang bersikeras menghapus pelacuran.

Pesantren di era modern dituntut untuk bisa menjawab tantangan zaman dan tidak hanya berkutat pada dunia pendidikan dalam arti hanya mencetak ilmuwan tetapi juga mencetak tenaga-tenaga terampil dan juga memberi manfaat pada lingkungan sekitar. Hal ini telah dilakukan oleh Kiai Sahal dan Pesantren Maslakul Huda.

dan Pengelolaannya", dalam Kumpulan Makalah KH. MA Sahal Mahfudh, Pati: Pesantren Maslakul Huda, 30 Maret.

. Aids dan Prostitusi dari Dimensi Islam", makalah disampaikan dalam Seminar Yaski Yogyakarta, 21 Juni 1987.

-1994. “Dakwah Untuk Kaum Dhua'afa"' dalam Figh Sosial, Yogyakarta: LkiS.

Mas'ud, Abdurrahman. 2000. Reformasi Pendidikan Agama Menuju Masyarakat Madani, dalam Ismail SM dan Abdul Mukti (ed), Pendidikan Islam, Demokratisasi dan Masyarakat Madani. cet . I.Yogyakarta: Pustaka Pelajar.

Purba,Jonny. 2002. Pengelolaan Lingkungan Sosial. Jakarta: Kantor Kementrian Lingkungan Hidup dan Yayasan Obor Indonesia.

Qamar,Mujamil. 2007. Pesantren dari Transformasi Metodologi Menuju Demokratisasi Institusi. Jakarta: Erlangga.

Raharjo,M. Dawam. 1988. Pesantren dan Pembaharuan. Cet. IV. Jakarta: LP3ES.

Sarijo,Marwan. 1982. Sejarah Pondok PeCreated with 
santren di Indonesia. Jakarta: Penerbit Dharma Bhakti.

SM, Ismail. 2002. Dinamika Pesantren dan Madrasah. Yogyakarta: Pustaka Pelajar.

Sunyoto,A. 1989. Ajaran Tasawuf dan Pembinaan Sikap Hidup Santri Pesantren Nurul Haq Surabaya: Studi Kasus.Tesis tidak dipublikasikan, Malang: FPS IKIP.

Tedjo, Sasongko. (ed.). 1997. Dialog Dengan KH MA Sahal Mahfudh. Semarang: Yayasan Karyawan Suara Merdeka.
Usa, Muslih dan Aden Wijdan. 1997. Pendidikan Islam Dalam Peradaban Industrial. Yogyakarta: Aditya Media.

Wahid,Abdurrahman. 1984. "Asal-Usul Tradisi Keilmuan Pesantren" dalam Jurnal Pesantren, No. Perdana, OktoberDesember.

2001. Pergulatan Negara, Agama, dan Kebudayaan. Jakarta: Desantara.

Zarnudji,A. 1963. Kitab Ta Timul Muta'alim. Kudus: Menara Kudus. 